Policy Studies

\title{
Social Security Contributions and Return Migration Among Older Male Mexican Immigrants
}

\section{Emma Aguila, $\mathrm{PhD}^{1, *}$ and Alma Vega, $\mathrm{PhD}^{2}$}

'Sol Price School of Public Policy, University of Southern California, Los Angeles. ${ }^{2}$ NewCourtland Center for Transitions and Health, University of Pennsylvania School of Nursing, Philadelphia.

*Address correspondence to Emma Aguila, PhD, Sol Price School of Public Policy, University of Southern California, 650 Childs Way, Los Angeles, CA 90089. E-mail: eaguilav@usc.edu

Received March 4, 2016; Editorial Decision date June 19, 2016

Decision Editor: John B. Williamson, PhD

\begin{abstract}
Purpose: For decades, scholars have studied the effects of immigration on the U.S. social security system. To date, this research has been primarily limited to migrants within the United States and does not consider those who return to their countries of origin. We estimate the proportion of male Mexican return migrants who contributed to the U.S. social security system and analyze their socioeconomic characteristics and migration histories. We also estimate the proportion that receive or expect to receive U.S. social security benefits.

Design and Methods: Using probit regression on the 2012 Mexican Health and Aging Study (MHAS), we describe the predictors of having contributed to the U.S. social security system among Mexican males in Mexico aged 50 years and older who at some point lived in the United States.

Results: We find that $32 \%$ of male return migrants reported having contributed to the U.S. social security system, but only $5 \%$ of those who contributed, received or expected to receive benefits. Those who reported having contributed spent more years in the United States and were more likely to be U.S. citizens or legal permanent residents than those who did not contribute. Implications: Immigrants often pay Old-Age, Survivors, and Disability Insurance taxes using legitimate or illegitimate social security numbers and return to their home countries without collecting U.S. social security benefits.
\end{abstract}

Keywords: Return migration, Social security, Retirement benefits

Scholars have long studied the effects of immigration on the U.S. social security system (e.g., Bongaarts, 2004; Gustman \& Steinmeier, 1998; Lee \& Miller, 2000; Storesletten, 2000). To date, this research has been primarily limited to migrants within the United States and has not considered those who return to their countries of origin. To our knowledge, there are only two studies that examine access to U.S. social security benefits among Mexican return migrants (Aguila \& Zissimopoulos, 2009; Ross, Pagan, \& Polsky, 2006). However, neither of these studies quantifies the proportion of return migrants that contributed to the U.S. social security system and that receive or expect to collect benefits.
The interaction between return migration and the U.S. social security system holds numerous policy implications. For one, return migration may affect the payroll tax required to keep the U.S. social security system solvent. Social security trust fund projections currently use indirect methods to estimate the proportion of emigrants that contributed to the U.S. social security system. Although such methods can provide a viable range, it is important to improve the accuracy of these estimates since the payroll taxes needed to fund the U.S. social security system can be sensitive to different assumptions surrounding migration (Wilmoth, 2005). 
In this study, we estimate the proportion of former U.S. migrant males in Mexico who contributed to the U.S. social security system. Specifically, we estimate the proportion of male return migrants aged 50 years and older who reported having contributed to the U.S. social security system and examine their demographic and migration characteristics. We also estimate the proportion of return migrants that receive or expect to receive U.S. social security benefits. Our study helps fill the sparse literature in this area and may contribute to policy decision making. In this way, the present study aims to inform the broader debate on the effects of immigration on the U.S. social security system by examining a population absent from most U.S. databases: Mexican return migrants.

\section{Background}

International migration will continue to exert great influence in the United States. According to U.S. Census Bureau projections, immigrants will increase from $13.3 \%$ of the U.S. population in 2014 to $18.8 \%$ in 2060 (Colby \& Ortman, 2015). Among the many ramifications of this development are its economic implications. General media (e.g., Camarota, 2015; Lee, 2015) and previous studies (e.g., Borjas \& Hilton, 1996; Hu, 1998) suggest that immigrants represent a burden to the U.S. economy. Although there is some information rebutting this claim (e.g., Smith \& Edmonston, 1997), few studies consider whether workers who return to their countries of origin contributed to the U.S. economy. Immigrants often pay Old-Age, Survivors, and Disability Insurance (OASDI) taxes using illegitimate social security numbers (Social Security Administration, Office of the Inspector General [SSA OIG], 2002), although this practice may have decreased since 2001 (Goss et al., 2013), and may return to their home countries without collecting benefits.

The presence of immigrants in the United States affects the balance between tax revenues and public expenditures (Smith \& Edmonston, 1997), the composition of the U.S. labor force (Singer, 2012) and the U.S. social security trust fund (Wilmoth, 2005). Trust fund projections currently depend on the number of legal and non-legal migrants entering and exiting the country (SSA, Office of the Chief Actuary [SSA OCA], 2014). Although there is a vibrant literature on the characteristics of entering migrants, there is far less information on migrants exiting the country. Studies document considerable migration among foreign-born primary social security beneficiaries (e.g., Turra \& Elo, 2008; Vega, 2015) but do not examine emigration among immigrants who are ineligible to collect benefits.

Duleep (1994) describes the state of the literature on how emigration affects the U.S. social security system as a "coarsely woven net of various strands of research, audacious assumptions, and rough approximations" (p. 31). As of the writing of Duleep's study, social security trust fund projections assumed that $83 \%$ of emigrants left the United States before becoming eligible for benefits. This estimate was based on historical data from the first half of the 20th century and indirect methods comparing Immigration and Naturalization Service to U.S. Census Bureau records. Direct estimates are needed of the proportion of Mexican emigrants that are ineligible to collect benefits.

A few empirical studies examine access to social security benefits among Mexican return migrants but none of them quantify the number of return migrants eligible to collect benefits. Ross and colleagues (2006) analyze the effect of U.S. migration experience on pension coverage during retirement among return migrants. Using the Mexican Health and Aging Study (MHAS) 2001, the authors find that an extra year spent in the United States is associated with a 0.4 percentage point increase in the probability of receiving pension benefits. The authors do not, however, distinguish whether these pension benefits come from U.S. or Mexican sources. Aguila and Zissimopoulos (2009) come to a more nuanced conclusion when dichotomizing return migrants into short-term (spent less than a year in the United States) and long-term (spent one or more years) U.S. migrants. Using the MHAS 2001 and 2003 waves, the authors find that short-term return migrants had similar access to Mexican social security benefits than Mexicans with no migration history to the United States and less access to U.S. social security benefits than long-term return migrants. Conversely, long-term return migrants were less likely to have access to Mexican social security benefits and more likely to access U.S. social security benefits than short-term migrants.

The gap in the literature on return migrants' contributions to the U.S. social security system is important given demographic changes resulting from the 1986 Immigration Reform and Control Act (IRCA). One purpose of this law was to enable unauthorized migrants to gain legal status if they fell into at least one of two categories: (a) farm workers who could demonstrate they had worked in the United States for at least 90 days during the 12 months preceding May 1, 1986 and (b) immigrants who could prove continuous residence in the United States after January 1, 1982 (Borjas \& Tienda, 1993). Nearly 2.7 million undocumented immigrants were granted legal permanent residence, representing almost 90\% of all applications (Rytina, 2002). Powers and Seltzer (1998) and Borjas and Tienda (1993) report that approximately $70 \%$ of immigrants legalized under IRCA were of Mexican origin and 50\% were aged 30 and older in 1990. The latter estimate implies that at least half of individuals legalized under IRCA were aged 52 years or older in 2012 .

As a result of obtaining legal status under IRCA, more migrants who reach retirement age will be eligible to receive U.S. social security benefits. Individuals must have at least 40 qualifying quarters of earnings. Benefits are not available to unauthorized immigrants and any noncitizen without a work-authorized social security number (Goss et al., 2013). 
IRCA legalized roughly half of all unauthorized immigrants in the United States in 1986 (Woodrow-Lafield \& Passel, 1990) who might otherwise not have obtained U.S. legal status.

Those who do not obtain U.S. legal status essentially forfeit their claim to U.S. social security benefits despite having contributed to the system. The Migration Policy Institute estimates that in 2013 the size of the unauthorized immigrant population was 11 million (Migration Policy Institute [MPI], n.d.). According to estimates for that year, around $56 \%$ or 6.2 million of unauthorized migrants were born in Mexico. In contrast, the legal Mexican-born population living in the United States was around 5.4 million. Structural factors that promote migration from Mexico to the United States include the availability of jobs in the United States and wage differentials between the two countries (Aguila et al., 2012).

When not authorized to work in the United States, immigrants cannot receive a legitimate social security number and are barred from participating in the retirement scheme. The social security number is a unique identifier which links individual's work credits to the U.S. social security system (SSA, n.d.). When reported wage items cannot be matched to the earning records of individual workers, as is the case when individuals use illegitimate social security numbers, an electronic file for these holdings is created. When a mismatch occurs between SSA records and the name listed on the wage forms, individuals cannot receive the corresponding work credits. These files are contained in the Earnings Suspense File (ESF; SSA, Office of Legislation and Congressional Affairs [OLCA], 2006). As of 2014, \$1.2 trillion in wages were posted to the ESF (SSA OIG, 2015), \$70 billion of which was added in 2011 alone (SSA OIG, 2014). Technically, a legal immigrant is eligible to collect benefits from wages made as an undocumented immigrant but few are thought to provide the required documentation (Goss et al., 2013). Many of these migrants may return to their countries of origin prior to qualifying for benefits.

The present study considers whether Mexican return migrants contributed to the U.S. social security system while in the United States. This study examines the proportion of return migrant males in Mexico aged 50 years and older who reported having contributed to the U.S. social security system, how many receive or expect to receive benefits, and their sociodemographic characteristics. This study departs from previous efforts by examining a population largely absent from U.S. databases: Migrants who returned to their home countries. In doing so, we attempt to provide a panoramic picture of the various cross-national entities who influence the U.S. social security system but are often left out of discussions regarding its solvency.

\section{Design and Methods}

Data

We use the MHAS for this study. Modeled after the Health and Retirement Study, the MHAS is one of the first panel surveys on the 50 and older population in the developing world and is well suited for examining older Mexican migrants as it oversampled regions with strong U.S. migration patterns. Because migrants were interviewed in Mexico, they may have been less incentivized to inaccurately answer questions about their experiences in the United States. This nationally representative three-wave survey was first conducted in 2001 and achieved a response rate of $90 \%$ out of 11,000 selected households (Instituto Nacional de Estadística, Geografía e Informática [INEGI], 2004; Wong \& Espinoza, 2004). The second wave reinterviewed the sample in 2003, achieving a response rate of $94.22 \%$ (INEGI, 2004; Wong \& Espinoza, 2004). The third wave reinterviewed individuals in 2012 and added new respondents to ensure representativeness of 50 and older population. More than 14,000 individuals in the 2001 and 2003 waves were reinterviewed in 2012, with the sample now totaling 20,542 individuals and having an overall response rate of $88 \%$ (INEGI, 2013).

Although we only analyze the 2012 cross-section, we use information from the 2001 and 2003 waves to verify and update information in the 2012 wave. For example, in the 2012 wave, many immigrants did not travel to the United States since 2003 and were skipped out of a series of questions regarding their experiences in the United States. For these cases, this information was filled in using their responses from prior waves. We do not analyze the 2001 wave because respondents were not asked whether they contributed to the U.S. social security system. We do not analyze the 2003 wave due to the large number of missing values in some of the independent variables. Moreover, there was little difference in the proportion who contributed to the U.S. social security system across the 2003 and 2012 waves.

\section{Sample}

Our sample includes Mexican-born males living in Mexico aged 50 years and older who at some point returned from the United States. Limiting the analysis to those aged 50 and older provides the advantage of omitting migrants who might still be at risk of reentering the United States and contribute to the U.S. social security system. Vega and Brazil (2015) find that less than 5\% of ex-U.S. migrant males in Mexico aged 50 years and older reentered the United States within the previous 5 years. Proxy responses are excluded because proxies were not asked a battery of questions related to migration experiences within the United States. Proxy interviews represented $10.6 \%(N=108 / 1,017$; analysis not shown) of all males aged 50 and older in 2012 who at some point returned from the United States.

In order to assess possible bias in excluding these respondents from the analysis, we predict the characteristics of proxy interviews using probit regression on variables available for proxy respondents (see online Supplementary Table I). We found that respondents with proxy interviews were less likely to be U.S. citizens or legal permanent 
residents upon controlling for age, education, and duration in the United States. This finding suggests that our estimates of the proportion of return migrants who contributed to the U.S. social security system may be downward biased in excluding proxies. Although not ideal, this is a far more desirable than the presence of upward bias, that is, overestimating the proportion of return migrants that contributed to the U.S. social security system.

We used the panel structure of the 2001, 2003, and 2012 waves to build a variable indicating whether a respondent reported living or working in the United States in any of the three waves using the following question: "Have you ever worked/lived in the U.S.?" We use the MHAS 2001 and 2003 waves to check the consistency of responses for the same individual across the three waves.

We exclude females due to their small sample size. Moreover, previous studies find that female employment is concentrated in the informal sector (e.g., Baker, 1997; Salcido \& Menjívar, 2012). Thus, females are potentially less likely to contribute to the U.S. social security system.

\section{Dependent Variables}

MHAS solicits information as to whether the respondent contributed to the U.S. social security system with the following question: "Did you ever contribute to the social security system in the U.S.?" Importantly, this question is likely to underestimate the proportion of all return migrants who contributed to the U.S. social security system because some migrants may not have been aware that they contributed. For this reason, our estimates likely represent a conservative lower bound.

Several survey items are used to determine whether migrants receive or expect to receive U.S. social security benefits. Our measure includes the expectation of receiving benefits, in addition to currently receiving benefits, because some migrants were not age-eligible to receive benefits but will receive benefits in the future. This information is obtained with a variable asking respondents if they received a retirement or other pension during the last year. If yes, respondents are then asked if the pension comes from U.S. social security. The expectation of receiving benefits is measured in an analogous fashion.

\section{Independent Variables}

Our independent variables are grounded on Duleep's (1994) theoretical framework and factors deemed important in the literature. Age was included in the models to account for temporal factors possibly influencing whether migrants contributed to the system. For example, immigrants in the United States aged 65 years and older in 1986 who otherwise met the requirements of IRCA were exempted from meeting the English-language requirement and more easily obtained legal permanent resident status (Sen Simpson, 1985). Education was included because it is associated with the amount of taxes migrants pay in the United States (Smith \& Edmonston, 1997). Duration in the United States was accounted for because it is associated with employment levels (Akresh, 2008; Chiswick, Cohen, \& Zach, 1997). Duleep (1994) notes that duration in the United States is also associated with the propensity to emigrate before becoming eligible to receive benefits. Because the number of years in the United States was positively skewed, a categorical version of this variable was used. The models control for the age at which the migrant first arrived to the United States because, according to Duleep (1994), it affects the age at which they emigrate. Similar to Campos Horta and Tienda (2015), we define working ages as 20-49 years because labor force participation drops precipitously among Mexican immigrant males who arrive after age 50. Citizenship status is included in the models to capture the higher risk of contributing to the U.S. social security system among immigrants with U.S. legal status. Although participation in the U.S. social security system is nearly universal among the general U.S. population, most workers in the informal economy are immigrants (Losby et al., 2002).

Unfortunately, age at arrival and citizenship/permanent residency status had a large number of missing values due to questionnaire skip patterns. Specifically, in 2001, some interviewees reported having never been to the United States and in 2003, reported having been to the United States but not within the previous 2 years. In the 2003 wave, those who had not been to the United States within the previous 2 years skipped out of a set of immigration questions including their age of arrival and U.S. citizenship. This situation applies to $11.0 \%$ of the final sample. We assessed the level of bias this contradictory information might create by comparing the demographic characteristics of respondents who did and did not provide contradictory information. We found that interviewees with a dispute were more likely to have spent less than 10 years in the United States than those without a dispute (see online Supplementary Table II). As such, these migrants may have had a lower probability of having contributed to the U.S. social security system and may further downward bias our estimates. Instead of dropping these cases, observations missing information for age of arrival and citizenship status are recoded into a separate analytical category. This is consistent with other studies (Flippen \& Tienda, 2000; Vega, 2016).

\section{Statistical Analysis}

Descriptive differences in the independent variables between those who did and did not contribute to the U.S. social security system were tested using a Pearson chi-squared test. Fisher's exact test was used for categorical variables with small cell sizes due to missing values, namely, education and duration in the United States. A probit model was used to predict whether migrants contributed to the U.S. 
social security system. We compared all estimates with and without the use of MHAS-provided sampling weights. We found minimal substantive differences in the outcome variables of interest and present unweighted estimates because they are more efficient (Korn \& Graubard, 1999). We also justify the use of unweighted estimates on the grounds that the MHAS weights reflect adjustments based on the migrant oversample and our analysis is restricted to migrants. Korn and Graubard (1999) suggest incorporating variables that reflect the survey design into the model as an alternative to applying population weights. Because of the large number of missing values for age of arrival and citizenship status, we conduct two probit regressions, one with and one without these variables. Comparing the results of both models provides a sense of the extent to which missing cases bias results. We also conducted robustness tests by restricting our sample to those aged 62 and older and, in separate analysis, those aged 65 and older.

\section{Results}

Table 1 shows that among ex-U.S. migrants, $32.0 \%$ reported having contributed to the U.S. social security system (Panel A). As previously noted, these are conservative

Table 1. Proportion of Mexican Males Aged 50 Years and Older Who at Some Point Returned From the United States That Contributed to the U.S. Social Security System

\begin{tabular}{lcr}
\hline Variables & $N$ & $\%$ \\
\hline Panel A: Proportion who reported having ever contributed to the \\
U.S. social security system & & \\
Total who lived in United States & 913 & 100.0 \\
Did not contribute & 562 & 61.6 \\
Contributed & 292 & 32.0 \\
Missing & 59 & 6.5 \\
Panel B: Proportion who reported receiving or expecting to receive \\
U.S. social security benefits & & \\
Total who contributed & 292 & 100.0 \\
Do not receive or expect to receive & 275 & 94.2 \\
Receive or expect to receive & 15 & 5.1 \\
Refused & 2 & 0.7 \\
\hline
\end{tabular}

Notes: Panel A: Of the 59 missing values, 16 reported not knowing whether they contributed to the U.S. social security system. Seven were only interviewed in 2001 and 2012 and did not visit the United States between 2003 and 2012. These respondents indicated having lived in the United States in 2001 but were not asked whether they contributed to the U.S. social security system in 2003 because they did not interview that year. They were also not asked this question in 2012 because they had not been to the United States between 2003 and 2012. Thirty-six were direct follow-up respondents who had proxy interviews in 2003 and reported not having been to the United States between 2003 and 2012. In 2003, follow-up proxy respondents were not asked whether the sampled individual had ever contributed to the U.S. social security system. Because the sampled individual did not travel to the United States since 2003, he was not asked in 2012 whether he had ever contributed to the U.S. social security system.

Source: Authors' calculations using the 2012 Mexican Health and Aging Survey (MHAS). estimates that do not capture migrants who were unaware of contributing to the U.S. social security system. More than half of males $(61.6 \%)$ reported not contributing to the U.S. social security system, implying that a large proportion of individuals may have worked in noncompliant firms in the United States.

Of those who contributed to the U.S. social security system, only $5.1 \%$ received or expected to receive benefits (Table 1: Panel B). This result supports the Office of the Chief Actuary's belief that relatively few migrants who could potentially draw benefits do so (Goss et al., 2013).

Table 2 shows that, compared to those who contributed to the U.S. social security system, those who did not contribute were younger. A higher proportion of those who contributed were aged 70 and older $(52.8 \%)$ compared to those who did not contribute $(36.4 \% ; p<.01)$. The educational composition of both groups was not statistically different. A similar proportion in both groups did not complete an elementary school education $(18.8 \%$ vs. $19.0 \%$, respectively).

Not surprisingly, those who contributed to the U.S. social security system lived in the United States longer than those who did not contribute. Twenty-two percent of those who contributed to the U.S. social security system lived in the United States at least 10 years compared to only $11.6 \%$ of those who did not contribute $(p<.01)$. As Mexican males are heavily driven to the United States for employment considerations (Cerrutti \& Massey, 2001), it is not farfetched to assume they worked most if not all of the years they spent in the United States. A lower proportion of those who contributed to the U.S. social security system were less than 50 years old when they first arrived to the United States, albeit a greater proportion were missing this information $(p$ $<.01)$. As previously stated, those who contributed are only eligible to receive U.S. social security benefits if they obtained U.S. legal status before retirement and contributed to the U.S. social security system for at least 40 quarters (10 years). We find that $21.2 \%$ of return migrants who had contributed were U.S. citizens or legal permanent residents. The relatively low proportion of return migrants with U.S. legal status helps explain why so few of those who contributed expected to collect benefits in the future $(5.1 \%$; Table 1$)$.

Among those who received or expected to receive U.S. social security benefits, $76.7 \%$ reported having lived 10 years or more in the United States compared to only $13.5 \%$ of those who do not expect to receive benefits (data not shown). The latter result implies that more than a 10th of return migrants that contributed to the U.S. social security system but did not expect to receive benefits spent more than 10 years in the United States and may be potentially eligible for U.S. social security benefits. They may not be able to receive benefits due to a lack of knowledge of the system or undocumented status while in the United States. The vast majority of those who do not expect to receive benefits, $85.9 \%$, spent less than 10 years in the United States (data not shown). 
Table 2. Demographic Characteristics of Mexican Males Aged 50 Years and Older in Mexico Who at Some Point Returned From the United States

\begin{tabular}{|c|c|c|c|c|}
\hline \multirow[b]{2}{*}{ Variables } & \multicolumn{2}{|c|}{ Did not contribute } & \multicolumn{2}{|c|}{ Contributed } \\
\hline & $N$ & $\%$ & $N$ & $\%$ \\
\hline Total & 562 & 100.0 & 292 & 100.0 \\
\hline \multicolumn{5}{|l|}{ Age } \\
\hline $50-59$ & $186 * * *$ & 33.1 & 56 & 19.2 \\
\hline $60-69$ & 171 & 30.4 & 82 & 28.1 \\
\hline $70-79$ & 139 & 24.7 & 103 & 35.3 \\
\hline $80+$ & 66 & 11.7 & 51 & 17.5 \\
\hline \multicolumn{5}{|l|}{ Education } \\
\hline Less than elementary school & 107 & 19.0 & 55 & 18.8 \\
\hline Elementary school & 308 & 54.8 & 164 & 56.2 \\
\hline More than elementary school & 145 & 25.8 & 71 & 24.3 \\
\hline Missing & 2 & 0.4 & 2 & 0.7 \\
\hline \multicolumn{5}{|l|}{ Years in United States } \\
\hline$<10$ & $494 * * *$ & 87.9 & 225 & 77.1 \\
\hline $10-19$ & 50 & 8.9 & 37 & 12.7 \\
\hline $20+$ & 15 & 2.7 & 28 & 9.6 \\
\hline Missing & 3 & 0.5 & 1 & 0.7 \\
\hline \multicolumn{5}{|l|}{ Age first migrated to United States } \\
\hline$<20$ & $68 * *$ & 12.1 & 56 & 19.2 \\
\hline $20-49$ & 363 & 64.6 & 160 & 54.8 \\
\hline $50+$ & 37 & 6.6 & 14 & 4.8 \\
\hline Missing & 94 & 16.7 & 62 & 21.2 \\
\hline \multicolumn{5}{|l|}{ Citizenship status } \\
\hline Citizen/permanent resident & $41 * * *$ & 7.3 & 62 & 21.2 \\
\hline $\begin{array}{l}\text { Not a citizen/ } \\
\text { permanent resident }\end{array}$ & 454 & 80.8 & 192 & 65.8 \\
\hline Missing & 67 & 11.9 & 38 & 13.0 \\
\hline
\end{tabular}

Notes: Mexican males aged 50 and older who did not provide information as to whether they contributed to the U.S. social security system ( $N=59$ ) are not included. Two observations were missing values as to their highest level of education due to questionnaire skip patterns. These respondents were not interviewed in 2001 but were treated as follow-up respondents in 2003 and not asked their highest level of education. Seven respondents did not know the age they first migrated to the United States, 5 refused to answer this question, 34 had information missing for this variable in previous years and had not been to the United States since their last interview, and 110 had missing information because of questionnaire skip patterns. In 2001, these respondents reported not having ever been to the United States and in 2003, reported having been to the United States but not within the past 2 years. These respondents were not asked a serious of questions regarding their migration experience including the age at which they first migrated to the United States and their citizenship status. Four respondents did not know how many years they had been in the United States and one refused to answer this question. Three respondents reported not knowing if they were U.S. citizens or legal permanent residents, and two respondents refused to answer this question. Seven respondents officially entered the study in 2001 but were not interviewed this year. Because these seven respondents did not travel to the United States in subsequent years, they were never asked whether they were U.S. citizens or legal permanent residents. Ninety-three respondents were missing information due to skip pattern issues described above. Of these 93 respondents, 57 reported not having contributed to the U.S. social security system and 36 reported having contributed.

$* p<.05, * p<.01, * * p<.001$.

Source: Authors' calculations using the 2012 Mexican Health and Aging Survey (MHAS).

We attempt to obtain a fuller picture of the characteristics associated with having contributed to the U.S. social security system via a probit regression model (Table 3). We present models that do and do not control for age at arrival and citizenship status to assess the extent to which the large number of missing values for these variables alters coefficients. Model 1 does not control for these variables. The similar coefficients for age and education across models suggest that cases missing age of arrival and citizenship status do not substantially bias estimates.

We find that increasing age, longer duration in the United States, younger age of arrival, and U.S. citizenship/legal permanent residence are associated with having contributed to the U.S. social security system. In both models, the probability of having contributed increases monotonically with age. Moreover, respondents who were in the United States 10-19 years were 11.6 percentage points more likely to have contributed than respondents who spent less than 10 years in the United States (Model 1). Respondents who spent at least 20 years in the United States were 32.3 percentage points more likely to have contributed than those who spent only 1-9 years in the United States (Model 1). The effect of duration in the United States is mitigated, however, upon controlling for age of arrival and citizenship 
Table 3. Probit Model Predicting Whether Ex-U.S. Migrant Males in Mexico Aged 50 Years and Older Contributed to the U.S. social security system (Average Marginal Coefficients)

\begin{tabular}{|c|c|c|}
\hline & $\beta /(S E)$ & $\beta /(S E)$ \\
\hline Variables & $(1)$ & $(2)$ \\
\hline \multicolumn{3}{|l|}{ Age group (ref.: 50-59) } \\
\hline $60-69$ & $\begin{array}{c}0.1010^{*} \\
(0.0393)\end{array}$ & $\begin{array}{c}0.0951 * \\
(0.0399)\end{array}$ \\
\hline $70-79$ & $\begin{array}{l}0.2108 * * * \\
(0.0426)\end{array}$ & $\begin{array}{l}0.1849 * * * \\
(0.0442)\end{array}$ \\
\hline $80+$ & $\begin{array}{l}0.2342 * * * \\
(0.0544)\end{array}$ & $\begin{array}{l}0.2199 * * * \\
(0.0549)\end{array}$ \\
\hline \multicolumn{3}{|c|}{$\begin{array}{l}\text { Highest level of education (ref: less } \\
\text { than elementary school) }\end{array}$} \\
\hline Elementary school & $\begin{array}{c}0.0389 \\
(0.0412)\end{array}$ & $\begin{array}{c}0.0389 \\
(0.0410)\end{array}$ \\
\hline More than elementary & $\begin{array}{c}0.0672 \\
(0.0502)\end{array}$ & $\begin{array}{c}0.0480 \\
(0.0499)\end{array}$ \\
\hline \multicolumn{3}{|c|}{ Years in the United States (ref: <10) } \\
\hline $10-19$ years & $\begin{array}{c}0.1164 * \\
(0.0552)\end{array}$ & $\begin{array}{c}0.0718 \\
(0.0562)\end{array}$ \\
\hline $20+$ & $\begin{array}{l}0.3226 * * * \\
(0.0738)\end{array}$ & $\begin{array}{l}0.1879 * \\
(0.0822)\end{array}$ \\
\hline \multicolumn{3}{|c|}{$\begin{array}{l}\text { Age first migrated to United States } \\
\text { (ref: } 50+\text { ) }\end{array}$} \\
\hline$<20$ & & $\begin{array}{l}0.1591^{*} \\
(0.0747)\end{array}$ \\
\hline $20-49$ & & $\begin{array}{c}0.0289 \\
(0.0642)\end{array}$ \\
\hline Missing & & $\begin{array}{c}0.0642 \\
(0.0844)\end{array}$ \\
\hline \multicolumn{3}{|l|}{ Citizen/legal permanent resident } \\
\hline Neither citizen/legal resident & & $\begin{array}{l}-0.2201 * * \\
(0.0591)\end{array}$ \\
\hline Missing & & $\begin{array}{l}-0.2238 * * \\
(0.0863)\end{array}$ \\
\hline Pseudo- $R^{2}$ & .0464 & .0683 \\
\hline Number of observations & 845 & 845 \\
\hline
\end{tabular}

Notes: Robust $S E$ s are presented.

*p<.10,**p<.05,***p<.01.

Source: Authors' calculations using the 2012 Mexican Health and Aging Survey (MHAS).

status. Upon controlling for these variables (Model 2), those who were in the United States 10-19 years were not more likely to have contributed and those who spent 20 or more years in the United States were only 18.8 percentage points more likely to have contributed. Combined, these two models suggest the strong effect of age of arrival and U.S. legal status in determining whether migrants contributed to the U.S. social security program. Model 2 also shows that, not surprisingly, migrants who first arrived to the United States as children were more likely to contribute than those who arrived at age 50 years and older.

We also analyzed whether contributions to the Mexican and U.S. social security systems could be substitutes but results were inconclusive. We found that a similar proportion of migrants who did and did not contribute to the U.S. social security system contributed to the Mexican social security system $(30.4 \%$ vs. $27.5 \%$, respectively; $p=.38$; analysis not shown). When introduced into Model 2 on Table 3, this variable was not statistically significant and did not improve the fit of the model. We also tested the robustness of our results by restricting the sample to those aged 62 and older and, in separate analysis, those aged 65 and older. We found that the direction of the predictors of interest did not change (results not shown).

\section{Discussion}

This is one of the few studies that examines whether Mexican return migrants contributed to the U.S. social security system and if they receive or expect to collect benefits. Although Turra and Elo (2008) and Vega (2015) examine the migration patterns of primary social security beneficiaries, these studies do not examine return migrants who contributed to the U.S. social security system but do not receive or expect to collect benefits. The main empirical finding in the present study is that in $2012,32 \%$ of return migrants reported having contributed to the U.S. social security system and, of those who contributed, only $5.1 \%$ received or expected to receive U.S. social security benefits.

Several factors emerge as possible explanations. Our results show that few of those who contributed and returned to Mexico had acquired U.S. legal status by the time of the survey, a prerequisite for collecting benefits (Goss et al., 2013). Technically, a legal immigrant is eligible to collect benefits from wages made as an undocumented immigrant but few are thought to provide the required documentation (Goss et al., 2013). In addition, our results show that many of these migrants did not spend the requisite number of years in the United States. Approximately $86 \%$ of those who contributed to the U.S. social security system and did not expect to receive benefits spent less than 10 years in the United States. It should be noted that most of those who contributed to the system (whether or not they expect to receive benefits) spent less than 10 years in the United States, indicating they did not contribute to the system for many years. However, the bulk of contributions to the ESF come from industries characterized by transient employment (SSA OIG, 2002), likely from individuals who did not contribute to the system many years. This suggests that short-term contributions, in aggregate, comprise a large part of the entire ESF. Yet another explanation for the low proportion of migrants who receive or expect to receive benefit is a lack of knowledge of the U.S. social security system. Return migrants who contributed to the U.S. social security system reported low levels of education: $75 \%$ completed an elementary education or less.

Several limitations are worth noting. We examine the characteristics associated with having contributed to the U.S. social security system, but we do not establish 
causal inference given the possibility of endogeneity bias. Nonetheless, this analysis provides a descriptive portrait that may be helpful in projecting the future effects of emigration on the U.S. social security system. There were also a large number of missing values among those who did and did not contribute to the U.S. social security system for age of arrival $(21.2 \%$ and $16.7 \%$, respectively) and U.S. citizenship/legal permanent residence $(13.0 \%$ and $11.9 \%$, respectively) primarily due to contradictory reporting by respondents. Nonetheless, introducing these two variables into the regression model did not substantially change results, save for the effect of duration in the United States, suggesting minimal bias. We also do not examine women due to small sample sizes. This limitation does not preclude the utility of this analysis, however, given the predominance of males among the ex-U.S. migrant population in Mexico (Aguila \& Zissimopoulos, 2009).

Yet another limitation is that due to data constraints, we are not able to determine the amount of social security contributions made by return migrants or the number of years they contributed to the system. Nonetheless, knowing the proportion of return migrants who contributed provides a necessary starting point for a comprehensive analysis of the economic implications of elderly return migration. Such an analysis would be a worthy future endeavor.

This calculation would require, at a minimum, a full U.S. employment history, the level of wages migrants received in each of these jobs, and their legal status while working in each of these jobs. It would then be possible to impose OASDI tax rates on wages and determine eligibility to claim benefits. This information could then be used to estimate the added revenues created by the contributions of Mexican return migrants to the U.S. social security system. Unfortunately, this information is not currently available in the MHAS. More detailed data are needed in order to construct models that predict the probability of contributing to the U.S. social security system for future generations, their eligibility to claim benefits, and the impact to the system.

Knowing the proportion of return migrants who contributed, however, elucidates an important component of the equation used to determine the solvency of the U.S. social security system. Different point estimates on the levels of international migration can have dramatically different effects on estimates of the payroll tax required to keep the system solvent (Wilmoth, 2005). Thus, although not a comprehensive account of the contributions of return migrants, our results move us closer to understanding a critical piece of this equation.

Currently, emigrants factor into U.S. social security trust fund projections as either legal immigrants who leave the population contributing to the U.S. social security system or undocumented immigrants who paid social security taxes or had no reported earnings while they were in the United States (SSA OCA, 2015). Our results show that more than one in three older Mexican return migrants had OASDI covered wages. This large number is surprising given that the vast majority of those who contributed $(65.8 \%)$ did not report being U.S. citizens or permanent residents at the time of the survey. Hence, even in light of restrictive immigration policies that bar undocumented immigrants from being employed in the United States, a substantial number still secure employment and contribute to the U.S. social security system. Moreover, as only $5.1 \%$ received or expected to receive U.S. social security benefits, the vast majority of those who contributed are not part of the insured population who at some point can expect to receive benefits.

It is worth highlighting that Mexican return migrants are a selected population. There is a large literature documenting the differences between Mexican emigrants to the United States compared to those who stay in Mexico (e.g., Chiquiar \& Hanson, 2005; Kaestner \& Malamud, 2013; Massey, 1987; Moraga, 2011; Rendall \& Parker, 2014) and a less prolific literature on the differences between return migrants compared to those who stay in the United States (e.g., Ambrosini \& Peri, 2012; Campos-Vazquez \& Lara, 2012; Lacuesta, 2010; Massey, 1987; Riosmena, Wong, \& Palloni, 2013; Van Hook \& Zhang, 2011). According to Borjas (1987), theoretically Mexican immigrants are negatively selected due to the higher wage inequality in Mexico than in the United States. According to the extended version of this theoretical model, Borjas and Bratsberg (1996) predict that Mexican emigrants are positively selected. However, there is no conclusive evidence as to whether immigrants or return migrants are positively or negatively selected on education, earnings, health, and other characteristics. These characteristics possibly influence immigrants' propensity to contribute to the U.S. social security system.

In the present study, we find that a lower proportion of return migrants were U.S. citizens or legal permanent residents compared to older Mexican immigrants in the United States (Sáenz, 2015). Our results, therefore, cannot be extrapolated to older Mexican immigrants in the United States given their stronger ties to the United States and likely greater propensity to contribute to the system. Nonetheless, this suggests that even though our sample represents those least likely to have contributed to the system (compared to all immigrants who enter the United States), a large proportion still contribute to the U.S. social security system. This finding sheds new light on the contentious national debate as to the effects of immigration on the U.S. economy.

Our results illuminate a potential added revenue to the U.S. social security system: The contributions of immigrants who will not receive benefits when they reach retirement age. Currently, the large reserve of illegitimate wages posted to the ESF (\$1.2 trillion as of 2014; SSA OIG, 2015) represent a liability in that individuals can potentially claim benefits from wages posted to this fund. Because a large portion of these reserves are thought to come from undocumented immigrants (SSA OIG, 2002), there has been some discussion from advocacy groups and other policy experts about 
expanding social programs for immigrant integration using funds from the ESF (e.g., Papademetriou, 2013; Spaulding, 2013). However, it may be complicated to distinguish the unclaimed work credits of undocumented immigrants from those resulting from legitimate errors such as name misspellings, digit transpositions in social security numbers, among others. Moreover, individuals are entitled to correct these type of errors while they are still working or even at the moment of applying for retirement benefits. The results from the present study suggest that a vast majority of migrants who post to the ESF and return to their home countries will not eventually draw upon this fund. These migrants contributed to the system, albeit typically for only a couple years, and emigrated before qualifying for benefits, thus providing added revenue to the U.S. social security program. Admittedly, this positive balance is just one of the myriad of factors that warrant attention in the complex equation determining the net costs and benefits of immigration to the U.S. economy (e.g., see Smith \& Edmonston 1997). Nonetheless, as the U.S. continues to age and put greater pressures on the U.S. social security program, the contributions of return migrants may take on added salience.

Despite this economic contribution, however, there are drawbacks to the large reserves in the ESF. By working in the United States, migrants disrupt their working lives in Mexico and potentially diminish their economic security during later life. More than one in five return migrants who contributed to the U.S. social security system spent a sizeable portion of their working lives in the United States, that is, $22.3 \%$ spent at least 10 years in the United States, but few expect to receive benefits. For over a decade, these migrants did not contribute to the Mexican social security system, possibly rendering them less likely to receive Mexican social security benefits. The Mexican pension system requires at least 10 or 25 years of contributions depending on whether individuals are subject to the requirements of the pre- or post-1997 pension reforms, respectively (Aguila \& Zissimopoulos, 2009). Aguila and Zissimopoulos (2009) find that only $21 \%$ of Mexican males aged 70 and older who spent more than a year in the United States received Mexican social security benefits compared to $30 \%$ of those who never traveled to the United States. Thus, by working in the United States and contributing the U.S. social security system in the process, ex-U.S. migrants may sacrifice Mexico-based retirement benefits for short-term U.S.-based wages. It is necessary to determine if these ex-U.S. migrants would indeed have contributed to the Mexican social security system if they had stayed in Mexico. Mexico's public pension contribution rates are quite low; the informal labor in Mexico was $57.8 \%$ of the labor force in 2014 (INEGI, 2015 ) and U.S. migrants may have been among the many who do not contribute to the Mexican social security system had they stayed. Instead, they may have to rely during retirement on social or noncontributory pensions that represent a minimum flat rate for poverty alleviation equivalent to US\$82.2 purchasing power parity per month in
2012 for individuals 70 or older (Aguila, Mejia, Perez-Arce, Ramirez, \& Rivera Illingworth, 2016).

Partially to reconcile these disruptions, the United States has established Totalization Agreements with 25 countries, mostly from western Europe and one Latin American country, Chile (SSA, n.d.). Totalization agreements are agreements between the United States and other countries to coordinate social security systems across two countries. One of the goals of these agreements is to integrate the work histories of workers who divided their careers between the United States and another country when determining their social security benefits. Under these agreements, migrants who worked in the United States could pool the years they worked in the United States and in the home country in order to qualify for home country benefits. Mexico currently does not have a Totalization Agreement with the United States. Although in 2004 the U.S. Social Security Commissioner and the General Director of the Mexican Social Security Institute signed a social security agreement between Mexico and the United States, it has not been formally approved by either government (Sullivan, 2005). Although the costs of such an agreement remain unclear (U.S. Government Accountability Office [GAO], 2003), opponents argue that this agreement would primarily favor Mexico (Dinerstein, 2014). Our results suggest that a Totalization Agreement with Mexico may enhance former U.S. migrants' ability to receive benefits during later life. However, this would depend on the specific rules of such an agreement such as whether undocumented immigrants would be allowed to claim benefits. As previously mentioned, there may be many challenges to accurately identify the work credits of undocumented immigrants. More detailed data sets are needed to identify whether Mexican return migrants who contributed to the U.S. social security system were documented or undocumented immigrants when they did so. Such information would enable estimation of different scenarios regarding the proportion of individuals that could benefit from such an agreement.

\section{Supplementary Material}

Please visit the article online at http://gerontologist.oxfordjournals.org/ to view supplementary material.

\section{Funding}

This work was supported by the U.S. Social Security Administration (UM15-17 to E.A. and A.V.) and the National Institute on Aging (T32AG000244 to A.V.).

\section{Acknowledgments}

We are grateful to Dalmer Hoskins, Zai Liang, James P. Smith, and participants of the 2015 Michigan Retirement Research Center Researcher Workshop and the 17th Annual Meeting of the Retirement Research Consortium (RRC) for helpful comments, and 
to Stephany Maqueda and Thalia Porteny for excellent research assistance. We also thank three anonymous reviewers whose comments helped improve the manuscript. The research reported herein was pursuant to a grant from the U.S. Social Security Administration (SSA), funded as part of the RRC. The findings and conclusions are solely those of the authors and do not represent the views of SSA, any agency of the federal government, the NBER Retirement Research Center, CRR, or MRRC.

\section{References}

Aguila, E., Akhmedjonov, A., Basurto-Davila, R., Kumar, K. B., Kups, S., \& Shatz, H. J. (2012). United States and Mexico: Ties That Bind, Issues That Divide. RAND Corporations. Retrieved August 8, 2016, from http://www.rand.org/pubs/monographs/ MG985-1.html

Aguila, E., Mejia, N., Perez-Arce, F., Ramirez, E., \& Rivera Illingworth, A. (2016). Costs of extending the noncontributory pension program for elderly: The Mexican case. Journal of Aging \& Social Policy, 28, 325-343. doi:10.1080/08959420.20 16.1158384

Aguila, E., \& Zissimopoulos, J. M. (2009). Labor Market and Immigration Behavior of Middle-Aged and Elderly Mexicans (SSRN Scholarly Paper No. ID 1533506). Rochester, NY: Social Science Research Network. Retrieved August 8, 2016, from http://papers.ssrn.com/abstract=1533506

Akresh, I. R. (2008). Occupational trajectories of legal US immigrants: Downgrading and recovery. Population and Development Review, 34, 435-456. doi:10.1111/j.1728-4457.2008.00231.x

Ambrosini, J. W., \& Peri, G. (2012). The determinants and the selection of Mexico-US migrants. The World Economy, 35, 111-151. doi:j.1467-9701.2011.01425.x

Baker, S. G. (1997). The "amnesty" aftermath: Current policy issues stemming from the legalization programs of the 1986 Immigration Reform and Control Act. The International Migration Review, 31, 5-27. doi:10.2307/2547255

Bongaarts, J. (2004). Population aging and the rising cost of public pensions. Population and Development Review, 30, 1-23. doi:10.1111/j.1728-4457.2004.00001.x

Borjas, G. J. (1987). Self-Selection and the Earnings of Immigrants (NBER Working Paper No. 2248). National Bureau of Economic Research, Inc. Retrieved August 8, 2016, from https://ideas. repec.org/p/nbr/nberwo/2248.html

Borjas, G. J., \& Bratsberg, B. (1996). Who leaves? The outmigration of the foreign-born. The Review of Economics and Statistics, 78, 165-176. doi:10.2307/2109856

Borjas, G. J., \& Hilton, L. (1996). Immigration and the welfare state: Immigrant participation in means-tested entitlement programs. The Quarterly Journal of Economics, 111, 575-604. doi:10.2307/2946688

Borjas, G. J., \& Tienda, M. (1993). The employment and wages of legalized immigrants. International Migration Review, 27, 712747. doi:10.2307/2546910

Camarota, S. A. (2015, January 6). Unskilled workers lose out to immigrants. The New York Times. Retrieved August 8, 2016, from http://www.nytimes.com/roomfordebate/2015/01/06/ do-immigrants-take-jobs-from-american-born-workers/ unskilled-workers-lose-out-to-immigrants

Campos Horta, M., \& Tienda, M. (2015). Of work and the welfare state: Labor market activity of Mexican origin seniors. In W. A. Vega, K.
S. Markides, J. L. Angel, \& F. M. Torres-Gil (Eds.), Challenges of Latino aging in the Americas (pp. 49-75). Cham, Switzerland: Springer International Publishing. Retrieved August 8, 2016, from http://link.springer.com/10.1007/978-3-319-12598-5_4

Campos-Vazquez, R. M., \& Lara, J. (2012). Self-selection patterns among return migrants: Mexico 1990-2010. IZA Journal of Migration, 1, 8. doi:10.1186/2193-9039-1-8

Cerrutti, M., \& Massey, D. S. (2001). On the auspices of female migration from Mexico to the United States. Demography, 38, 187-200. doi:10.1353/dem.2001.0013

Chiquiar, D., \& Hanson, G. H. (2005). International migration, selfselection, and the distribution of wages: Evidence from Mexico and the United States. Journal of Political Economy, 113, 239281. doi:10.1086/427464

Chiswick, B. R., Cohen, Y., \& Zach, T. (1997). The labor market status of immigrants: Effects of the unemployment rate at arrival and duration of residence. Industrial and Labor Relations Review, 50, 289. doi:10.2307/2525087

Colby, S. L., \& Ortman, J. M. (2015). Projections of the Size and Composition of the U.S. Population: 2014 to 2060 (Report No. P251143). Washington, DC: U.S. Census Bureau. Retrieved August 8, 2016, from http://www.census.gov/library/publications/2015/demo/ p25-1143.html

Dinerstein, M. (2014, November 6). Social Security “Totalization": Examining a Lopsided Agreement with Mexico. Retrieved May 25, 2016, from http://cis.org/SocialSecurityTotalization-Mexico

Duleep, H. O. (1994). Social Security and the emigration of immigrants. Social Security Bulletin, 57, 37-52.

Flippen, C., \& Tienda, M. (2000). Pathways to retirement: Patterns of labor force participation and labor market exit among the preretirement population by race, Hispanic origin, and sex. Journal of Gerontology: Psychological Sciences and Social Sciences, 55, 14-27. doi:10.1093/geronb/55.1.S14

Goss, S., Wade, A., Skirvin, J. P., Morris, M., Bye, K. M., \& Huston, D. (2013). Effects of Unauthorized Immigration on the Actuarial Status of the Social Security Trust Funds (Actualial Note No. 151). Baltimore: Social Security Administration. Office of the Chief Actuary. Retrieved August 8, 2016, from http://www. socialsecurity.gov/oact/NOTES/pdf_notes/note151.pdf

Gustman, A., \& Steinmeier, T. (1998). Social Security Benefits of Immigrants and U.S. Born (No. w6478). Cambridge, MA: National Bureau of Economic Research. Retrieved August 8, 2016, from http://www.nber.org/papers/w6478.pdf

Hu, W.-Y. (1998). Elderly immigrants on welfare. The Journal of Human Resources, 33, 711-741. doi:10.2307/146339

Instituto Nacional de Estadística, Geografía e Informática. (2004). Estudio Nacional de Salud y Envejecimiento en México (ENASEM) 2001 Documento Metodológico Reporte de Proyecto. Retrieved August 8, 2016, from http://mhasweb.org/Resources/DOCUMENTS/2001/Methodological_ Document_2001.pdf

Instituto Nacional de Estadística, Geografía e Informática. (2013). Estudio Nacional de Salud y Envejecimiento en México (No. Boletín de Prensa Núm. 389/13) (p. 1/2). Aguascalientes, Ags. Retrieved August 8, 2016, from http://www.inegi.org.mx/est/ contenidos/proyectos/encuestas/hogares/especiales/enasem/doc/ enasem2013_09.pdf

Instituto Nacional de Estadística, Geografía e Informática. (2015). Derechohabiencia y uso de servicios de salud Población 
protegida por los servicios de salud, 2000 a 2014. Retrieved May 26, 2016, from http://www3.inegi.org.mx/sistemas/sisept/ default.aspx? $t=m s o c 01 \& s=e s t \& c=22594$

Kaestner, R., \& Malamud, O. (2013). Self-selection and international migration: New evidence from Mexico. Review of Economics and Statistics, 96, 78-91. doi:10.1162/REST_a_00375

Korn, E. L., \& Graubard, B. I. (1999). Analysis of health surveys: Korn/analysis. Hoboken, NJ: John Wiley \& Sons, Inc. doi:10.1002/9781118032619

Lacuesta, A. (2010). A revision of the self-selection of migrants using returning migrant's earnings. Annals of Economics and Statistics, 97/98, 235-259. doi:10.2307/41219117

Lee, K. (2015). Arizona crowd welcomes Donald Trump's tough stance on immigration. Los Angeles Time. Retrieved August 8, 2016, from http://www.latimes.com/nation/politics/la-natrump-arizona-rally-20150710-story.html

Lee, R., \& Miller, T. (2000). Immigration, social security, and broader fiscal impacts. The American Economic Review, 90, 350-354. doi:10.1257/aer.90.2.350

Losby, J. L., Else, J. F., Kingslow, M. E., Edgcomb, E. L., Malm, E. T., \& Kao, V. (2002). Informal Economy Literature Review. Retrieved August 8, 2016, from http://www.kingslow-assoc. com/images/Informal_Economy_Lit_Review.pdf

Massey, D. S. (1987). Understanding Mexican migration to the United States. American Journal of Sociology, 92, 1372-1403.

Migration Policy Institute [MPI]. (n.d.). Profile of the Unauthorized Population: United States. Retrieved August 8, 2016, from http:/ www.migration policy.org/data/unauthorized-immigrantpopulation/state/US

Moraga, J. F.-H. (2011). New evidence on emigrant selection. Review of Economics and Statistics, 93, 72-96. doi:10.1162/ REST_a_00050

Papademetriou, D. G. (2013, March 12). The fundamentals of immigration reform. The American Prospect. Retrieved August 8, 2016, from http://prospect.org/article/fundamentals-immigration-reform

Powers, M. G., \& Seltzer, W. (1998). Occupational status and mobility among undocumented immigrants by gender. International Migration Review, 32, 21-55. doi:10.2307/2547559

Rendall, M. S., \& Parker, S. W. (2014). Two decades of negative educational selectivity of Mexican migrants to the United States. Population and Development Review, 40, 421-446. doi:10.1111/j.1728-4457.2014.00692.x

Riosmena, F., Wong, R., \& Palloni, A. (2013). Migration selection, protection, and acculturation in health: A binational perspective on older adults. Demography, 50, 1039-1064. doi:10.1007/ s13524-012-0178-9

Ross, S. J., Pagan, J. A., \& Polsky, D. (2006). Access to health care for migrants returning to Mexico. Journal of Health Care for the Poor and Underserved, 17, 374-385. doi:10.1353/ hpu.2006.0067

Rytina, N. (2002). IRCA Legalization Effects: Lawful Permanent Residence and Naturalization Through 2001 (Working Paper). Office of Policy and Planning, Statistics Division, U.S. Immigration and Naturalization Service. Retrieved August 8, 2016, from https://www.dhs.gov/xlibrary/assets/statistics/publications/irca0114int.pdf

Sáenz, R. (2015). The demography of the elderly in the Americas: The case of the United States and Mexico. In W.A. Vega, K. S. Markides, J. L. Angel, \& F. M. Torres-Gil (Eds.), Challenges of Latino aging in the Americas (1st ed., pp. 197-223). Cham, Switzerland: Springer International Publishing. Retrieved August 8, 2016, from http:// link.springer.com/chapter/10.1007/978-3-319-12598-5_12

Salcido, O., \& Menjívar, C. (2012). Gendered paths to legal citizenship: The case of Latin-American immigrants in Phoenix, Arizona. Law \& Society Review, 46, 335-368. doi:10.1111/j.1540-5893.2012.00491.x

Sen Simpson, A. K. (1985, May 23). S.1200-Immigration Reform and Control Act of 1986 [Legislation]. Retrieved August 8, 2016, from https://www.congress.gov/bill/99th-congress/senate-bill/1200

Singer, A. (2012). Immigrant Workers in the United States Labor Force. The Brookings Institution. Retrieved August 8, 2016, from http:// www.brookings.edu/ /media/research/files/papers/2012/3/15immigrant-workers-singer/0315_immigrant_workers_singer.pdf

Smith, J. P., \& Edmonston, B. (1997). The new Americans: Economic, demographic, and fiscal effects of immigration. Washington, DC: National Academies Press. Retrieved August 8, 2016, from http://www.nap.edu/catalog/5779

Social Security Administration. (n.d.). International Programs-U.S. International Social Security Agreements. Retrieved May 25, 2016, from https://www.ssa.gov/international/agreements_overview.html

Social Security Administration, Office of the Chief Actuary. (2014). The Long-Range Demographic Assumptions for the 2014 Trustees Report. Retrieved August 8, 2016, from https:// www.ssa.gov/oact/tr/2014/2014_Long-Range_Demographic_ Assumptions.pdf

Social Security Administration, Office of the Chief Actuary. (2015). Long-Range OASDI Projection Methodology (Intermediate Assumptions of the 2015 Trustees Report). Baltimore. Retrieved August 8, 2016, from https://www.ssa.gov/oact/tr/2015/2015_LR_ Model_Documentation.pdf

Social Security Administration, Office of the Inspector General. (2002). Status of the Social Security Administration's Earnings Suspense File (Congressional Response Report No. A-03-0323038). Baltimore. Retrieved August 8, 2016, from https://oig. ssa.gov/sites/default/files/audit/full/pdf/A-03-03-23038.pdf

Social Security Administration, Office of the Inspector General. (2014). Fiscal Year 2015 Annual Work Plan. Retrieved August 8, 2016, from https://oig.ssa.gov/sites/default/files/audit/full/pdf/ FY\%202015\%20Audit\%20Plan.pdf

Social Security Administration, Office of the Inspector General. (2015). Status of the Social Security Administration's Earnings Suspense File (Informational Report No. A-03-15-50058). Retrieved August 8, 2016, from https://oig.ssa.gov/sites/default/ files/audit/full/pdf/A-03-15-50058.pdf

Social Security Administration, Office of Legislation and Congressional Affairs. (2006). Statement of James B. Lockhart III, Deputy Commissioner of Social Security. Retrieved August 8, 2016, from http://www.ssa.gov/legislation/testimony_021606. html

Spaulding, J. (2013, September 23). Literacy Coalition Backs NSC CIR Proposal. National Skills Coalition. Retrieved August 8, 2016, from http://www.nationalskillscoalition.org/news/blog/literacy-coalitionbacks-nsc-cir-proposal

Storesletten, K. (2000). Sustaining fiscal policy through immigration. Journal of Political Economy, 108, 300-323. doi:10.1086/262120

Sullivan, L. A. (2005). Totalization agreement between the United States and Mexico: An opportunity for improved relations and mutual benefit. LBJ Journal of Public Affairs, 18, 18. 
Turra, C. M., \& Elo, I. T. (2008). The impact of salmon bias on the Hispanic mortality advantage: New evidence from social security data. Population Research and Policy Review, 27, 515-530. doi:10.1007/s11113-008-9087-4

U.S. Government Accountability Office. (2003). Social security: Proposed totalization agreement with Mexico presents unique challenges (No. GAO-03-993). Retrieved August 8, 2016, from http://www.gao.gov/assets/240/239911.pdf

Van Hook, J., \& Zhang, W. (2011). Who stays? Who goes? Selective emigration among the foreign-born. Population Research and Policy Review, 30, 1-24. doi:10.1007/s11113010-9183-0

Vega, A. (2015). The impact of social security on return migration among Latin American elderly in the US. Population Research and Policy Review, 34, 307-330. doi:10.1007/ s11113-014-9339-4

Vega, A. (2016). The time intensity of childcare provided by older immigrant women in the United States. Research on Aging. doi:10.1177/0164027515626774
Vega, A., \& Brazil, N. (2015). A multistate life table approach to understanding return and reentry migration between Mexico and the United States during later life. Demographic Research, 33, 1211-1240. doi:10.4054/DemRes.2015.33.43

Wilmoth, J. R. (2005). Some methodological issues in mortality projection, based on an analysis of the U.S. social security system. GENUS, 61, 179-211.

Wong, R., \& Espinoza, M. (2004). Imputation of Non-response on Economic Variables in the Mexican Health and Aging Study (MHAS/ENASEM) 2001. Retrieved August 8, 2016, from http:// mhasweb.org/Resources/DOCUMENTS/2001/Imputation_ of_Non-Reponse_on_Economic_Variables_in_the_MHASENASEM_2001.pdf

Woodrow-Lafield, K., \& Passel, J. (1990). Post-IRCA undocumented immigration to the United States: Assessment based on the June 1988 CPS. In F. Bean, B. Edmonston, J. Passel (Eds.), Undocumented migration to the United States: IRCA and the experience of the 1980s (1st ed., p. 33). Washington, DC: The Urban Institute Press. 